\title{
Production of BP178, a derivative of the synthetic antibacterial peptide BP100, in the rice seed endosperm
}

\author{
Laura Montesinos ${ }^{1}$, Mireia Bundó ${ }^{2}$ Esther Badosa ${ }^{1}$, Blanca San Segundo ${ }^{2}$, María Coca $^{2}$ and Emilio Montesinos ${ }^{1 *}$ (D)
}

\begin{abstract}
Background: BP178 peptide is a synthetic BP100-magainin derivative possessing strong inhibitory activity against plant pathogenic bacteria, offering a great potential for future applications in plant protection and other fields. Here we report the production and recovery of a bioactive BP178 peptide using rice seeds as biofactories.

Results: A synthetic gene encoding the BP178 peptide was prepared and introduced in rice plants. The gene was efficiently expressed in transgenic rice under the control of an endosperm-specific promoter. Among the three endosperm-specific rice promoters (Glutelin B1, Glutelin B4 or Globulin 1), best results were obtained when using the Globulin 1 promoter. The BP178 peptide accumulated in the seed endosperm and was easily recovered from rice seeds using a simple procedure with a yield of $21 \mu \mathrm{g} / \mathrm{g}$. The transgene was stably inherited for at least three generations, and peptide accumulation remained stable during long term storage of transgenic seeds. The purified peptide showed in vitro activity against the bacterial plant pathogen Dickeya sp., the causal agent of the dark brown sheath rot of rice. Seedlings of transgenic events showed enhanced resistance to the fungal pathogen Fusarium verticillioides, supporting that the in planta produced peptide was biologically active.
\end{abstract}

Conclusions: The strategy developed in this work for the sustainable production of BP178 peptide using rice seeds as biofactories represents a promising system for future production of peptides for plant protection and possibly in other fields.

Keywords: Antimicrobial peptide, Oryza sativa, Rice biofactory, Protein bodies, Peptide recovery, Pathogen resistance

\section{Background}

Antimicrobial peptides (AMPs) are components of the innate immune system in animals and plants, and play an important role in antagonistic relationships between microorganisms [1-5]. There is a great expectation in biotechnological applications of AMPs that include their use as therapeutic agents, biopreservatives in cosmetics, materials and food; and substitutes of antibiotics in animal feed and in crop protection. AMPs are of particular interest in the field of crop protection because they meet the regulatory requirements for low environmental impact of pesticides [3]. However, the exploitation of natural AMPs presents limitations, as they are

\footnotetext{
*Correspondence: emilio.montesinos@udg.edu

${ }^{1}$ Institute of Food and Agricultural Technology-CIDSAV-XaRTA, University of

Girona, Girona 17071, Spain

Full list of author information is available at the end of the article
}

produced in low amounts in the living organisms and their extraction and purification requires complex and costly procedures. In addition, natural AMPs might show toxicity against non-target organisms [6].

The rational design of AMPs may overcome these limitations by developing peptides with improved biological properties, like increased antimicrobial activity and stability, and reduced toxicity against non-targeted organisms [7-9]. In this context, a library of synthetic linear undecapeptides consisting of cecropin A (1-7)melittin (2-9) hybrids (named CECMEL11 library), was previously obtained by combinatorial chemistry [8]. Several peptides from this library showed potent antibacterial and/or antifungal activities with low cytotoxicity (hemolytic and phytotoxic activity) and moderate susceptibility to proteolytic degradation [6]. Among them, the BP100 peptide exhibited strong activity against 
phytopathogenic bacteria and was effective in controlling infections by different phytopathogens in apple, pear, tomato and pepper [7]. Another set of CECMEL11 peptides (e.g. BP15, BP21) showed fungicidal activity and were effective in the control of postharvest rot of fruits [10] and brown spot of pear trees [11]. Some of the CECMEL11 peptides (e.g. BP100, BP16) had cell penetrating properties in eukaryotic cells and have already been used to deliver conjugated "cargo" compounds intracellularly $[12,13]$. Thus, CECMEL11 peptides represent useful tools in different fields of application. However, their exploitation requires the development of sustainable and feasible means of production.

Production of AMPs in living systems used as biofactories appears to be a promising alternative to the chemical synthesis [14]. Several prokaryotic and eukaryotic expression systems for the production of heterologous proteins or peptides have been described using microbial, insect or mammalian cells, and plants. All have advantages and disadvantages, depending on the type of protein to be produced, the complexity of downstream processes to recover it, and the cost. Microbial systems based on bacteria and yeasts, provide high yield production by fermentation processes and are easy to handle, but the inclusion body formation requires solubilization and refolding [15-17]. Procedures and the use of insect and mammalian cells, or transgenic animals are complex and expensive, with the additional disadvantages of the slow-scaling up and the ethical concerns [18]. Transgenic plants offer several advantages for production of AMPs in a cost effective manner, and therapeutic proteins have already been produced [19-28]. In recent years, commercial plant-derived proteins have been produced using cereal seeds [27, 29-32], and rice has been chosen in several cases as a platform [23, 33, 34]. Different rice promoters showing a seed-specific expression pattern have been described $[35,36]$, and valuable recombinant proteins including vaccines, antibodies, cytokines, hormones or enzymes have been successfully produced in rice seeds [31, 37-42]. Most of these rice based platforms produced peptides as multimers [43-45] or as a fusion to a large protein carrier such as storage proteins [46-50]. However, several reports show the difficulty to produce small peptides in the rice seed due to its small size, low stability and/or susceptibility to protease degradation in planta $[44,47,49,51]$. In order to achieve the production of CECMEL11 peptides using plant biofactories, synthetic analogs of the BP100 peptide that fulfill specific requirements for optimal production in plants were previously described [52]. Peptide modifications were made to increase peptide size, and to incorporate retention signals targeting the peptide to specific cell compartments (protein bodies, $\mathrm{PB}$ ). A priori this strategy reduces the risks of AMP degradation and/or toxicity towards plant cells. The compounds (e.g. BP178) were evaluated for antimicrobial, hemolytic and cytotoxic activities, and several were considered as suitable candidates to be produced in plant biofactories.

The aim of the present study was to determine the feasibility of using the rice seed as a biofactory to produce and recover a BP100 derivative, the BP178 antibacterial peptide ( 29 amino acids, $M W=3.2 \mathrm{kDa}$ ). This peptide has a lytic mode of action on several plant pathogenic bacteria. Promoters of rice seed storage protein genes were used to direct endosperm-specific expression of the $A M P$ gene, and stable transgenic rice plants accumulating the AMP in the seed endosperm were generated. The peptide was easily purified from rice seeds, and showed antimicrobial activity. Moreover, transgenic seedlings showed resistance to pathogen infection suggesting that the plant produced BP178 peptide was also biologically active in the rice seed.

\section{Results}

Based on the library of BP134 derivatives [52], in which modifications in peptide sequences were introduced to facilitate their production in plant systems, we selected the BP178 peptide for its production in rice seeds. This peptide consisted of a magainin fragment linked to the original sequence of the BP134 through an AGPA hinge region, and the KDEL retention signal sequence (KKLFKKILKYLAGPAGIGKFLHSAK-KDEL-OH) at the C-terminus (Additional file 1). We reasoned that retention into the endoplasmatic reticulum will protect the peptide from proteolytic degradation while reducing the risk of toxicity to the plant cell. The BP178 peptide exhibited strong bactericidal effect against several plant pathogenic bacteria with very low hemolytic activity. Phytotoxicity of BP178 to tobacco cells was observed by infiltration only at concentrations 50-100 times higher than minimal inhibitory concentration MIC values [52]. The selected peptide has a strong cationic net charge $(\mathrm{pI}=10.84)$ with an amphipathic character (Additional file 2).

\section{Generation and characterization of transgenic rice plants expressing a synthetic BP178 gene in seed tissues}

Three different constructs were obtained in which the synthetic $B P 178$ gene was cloned under the control of an endosperm-specific rice promoter (i.e. $p$ GluB1:BP1 78:nos, $p$ GluB4:BP178:nos and pGlb1:BP178:nos) (Fig. 1). The promoters and the signal peptide coding sequence of the rice glutelin $B 1, B 4$ and globulin genes were used to direct the expression of the $B P 178$ gene and accumulation of the transgene product in the seed endosperm.

Transgenic T0 and homozygous plants were morphologically similar to the wild-type untransformed plants.

All the regenerated rice lines recovered from different transformation events had the complete cassette for 


\section{a}
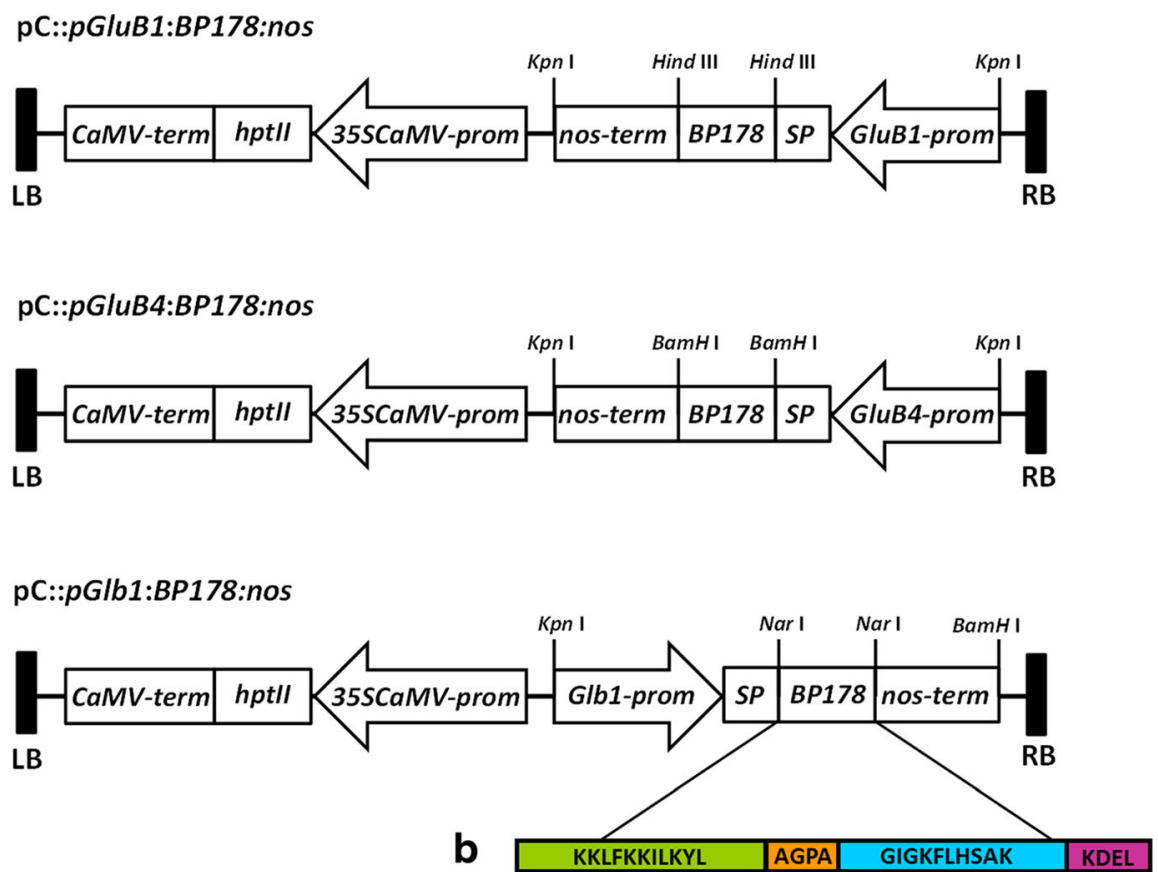

Fig. 1 Schematic representation of the plant expression vectors for the expression of the BP178 gene in the rice endosperm. a Three different constructs in PCAMBIA vector $(\mathrm{pC})$ in which the synthetic gene was cloned between the endosperm-specific promoter including the signal peptide coding sequence of the corresponding seed storage protein (SP) and the nopaline synthase terminator (nos). Relevant restriction enzyme sites for cloning purposes are indicated. The hptll gene encoding resistance to hygromycin under the control of the CaMV35S promoter and terminator was contained into the T-DNA region of $\mathrm{pC}$. LB, left border; RB, right border of T-DNA. Arrows indicate the orientation of the sequence. $\mathbf{b}$ The chimeric BP178 peptide corresponding to the fusion of BP134 (KKLFKKILKYL-OH, a cecropin A (1-7)-melittin (2-9) hybrid, in green) linked through the hinge sequence (AGPA, in orange) to a magainin fragment peptide (GIGKFLHSAKKFGKAFVGEIMNS -OH, in blue); and extended with ER retention signal (KDEL, in pink). For details, see Additional file 1: Figure S1

BP178 expression integrated into their genomes, as revealed by $\mathrm{PCR}$ analysis and subsequent sequencing of the PCR products (Additional file 3). Most transgenic lines carried a single copy insertion of both selectable marker and the BP178 gene, that is $66.0 \%$ for the pGlb1:BP178-lines, $100 \%$ for the $p G l u B 4: B P 178$-lines and $50 \%$ for the $p G l u B 1: B P 178$-lines. As expected, a 3:1 segregation ratio was observed in T0 events harbouring a single copy of the transgene. Single copy events were used as the parental lines to obtain homozygous lines in the T2 generation. Thus, independent homozygous lines from $p$ CGlb1:BP178:nos (5 lines), pCGluB4:BP178:nos (3 lines) and $p C G l u B 1: B P 178: n o s$ (3 lines) transformation events were selected for further analysis. Additionally, qPCR analysis confirmed stable transgene inheritance through successive generations (at least up to the T4 generation).

\section{Production and accumulation of BP178 peptide in transgenic rice seeds}

The total protein profiles of transgenic and WT seeds were initially examined by SDS-PAGE, and no significant differences were observed in the accumulation of native storage proteins (e.g. glutelins, prolamins) when comparing transgenic and WT seed protein profiles (Fig. 2a and b).

The promoters and the signal peptide coding sequence of the rice glutelin $B 1, B 4$ and globulin genes were used to direct the expression of the BP178 gene and accumulation of the transgene product. Previous studies demonstrated the capability of these regulatory sequences to produce the cecropin A peptide in the protein bodies of the rice endosperm. Accordingly, in this work we prepared protein body ( $\mathrm{PB}$ )-enriched fractions from mature seeds of transgenic lines harbouring a BP178 construct following the procedure previously described [54] (Additional file 4).

Western-blot analysis of $\mathrm{PB}$ proteins, using an antiBP178 polyclonal antibody, revealed accumulation of an immunoreactive band, putatively BP178 peptide, in the $\mathrm{PB}$ enriched fraction of the transgenic seeds harbouring the $p G l b 1: B P 178$ construct, which was absent in the same fraction of the empty vector seeds (Fig. 2c). Also, a large variation in accumulation of BP178 was observed among the different $p G l b 1: B P 178$ lines generated (Additional file 5). We also noticed that the apparent molecular weight of the BP178 peptide in Tricine-SDS PAGE was larger $(\sim 8 \mathrm{kDa})$ than the expected molecular 


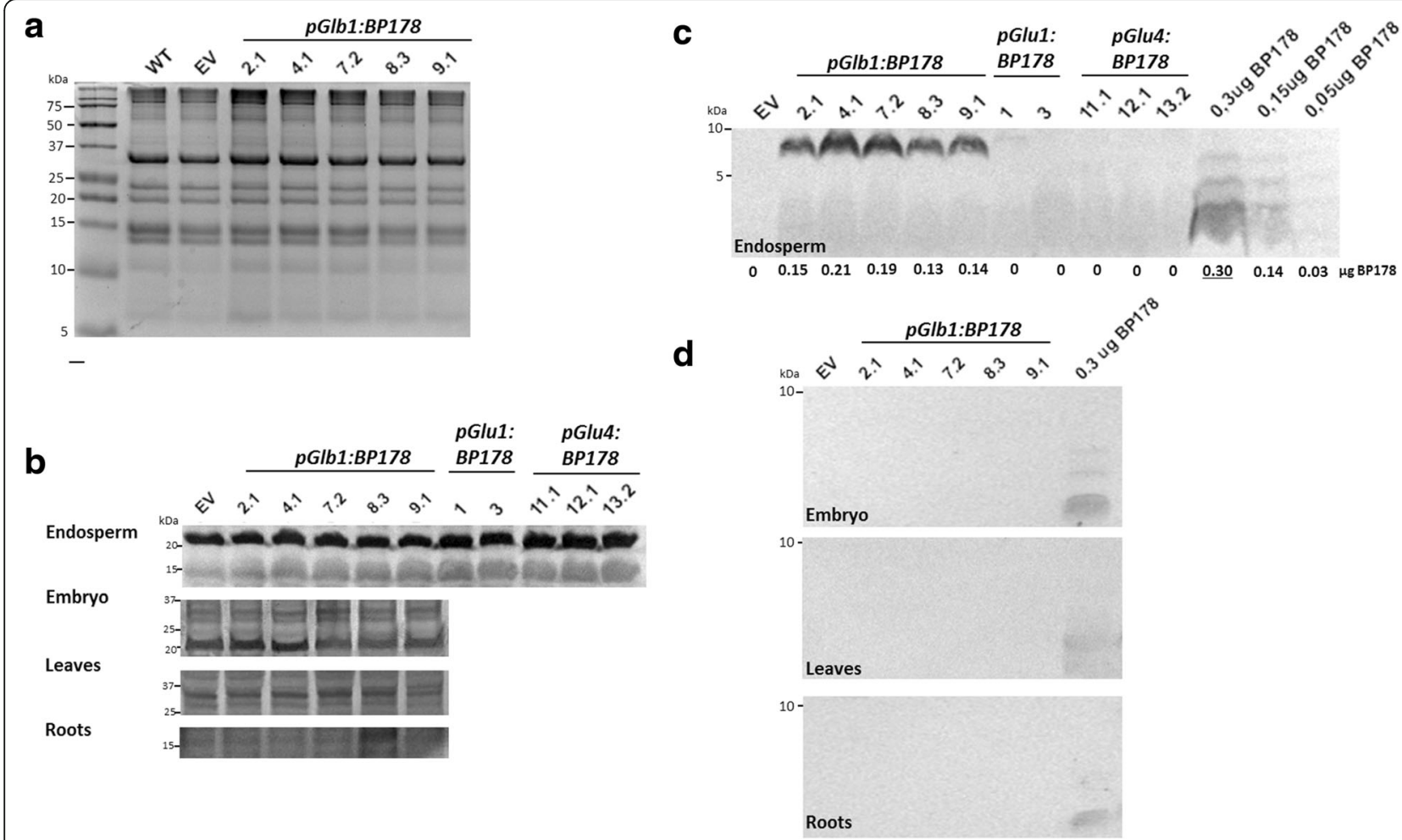

Fig. 2 BP178 peptide accumulates in the endosperm of Glb1:BP178 transgenic rice seeds without altering accumulation levels of native storage proteins. a Coomassie Blue staining of PB extracts from the indicated seeds. EV indicates seeds from plants transformed with the pCAMBIA 1300 empty vector. $\mathbf{b}$ Ponceau staining of protein samples $(50 \mu \mathrm{g}) \mathbf{c}$ Western-blot analysis and quantification of the BP178 peptide in the protein body-enriched fractions $(50 \mathrm{\mu g})$ from mature seed endosperms of the indicated pGlb1:BP178, pGluB4:BP178, pGluB1:BP178 and empty vector (EV) lines. The accumulation levels of BP178 peptide were quantified with the Quantity tools of the Chemidoc program using the $0.3,0.15$ and $0.05 \mu \mathrm{g}$ amounts of synthetic BP178 peptide as a reference (taking into account the sum of the three bands observed). Numbers below the western blot lanes correspond to $\mu \mathrm{g}$ of BP178 peptide. $\mathbf{d}$ Western-blot analysis of protein body-enriched fractions (50 $\mu \mathrm{g})$ from embryos, leaves or roots of the indicated pGlb1:BP178, and empty vector (EV) lines. For comparative purposes, $0.30,0.15$ and $0.05 \mu \mathrm{g}$ of synthetic BP178 peptide were run simultaneously in the Tricine-SDS gels. Immunodetection was performed using specific polyclonal anti-BP178KDEL antibodies and coloured phosphatase alkaline reaction

weight for the corresponding peptide $(3.2 \mathrm{kDa})$. In addition, when high concentrations of the synthetic BP178 peptide were subjected to immunoblot analysis, at least three immunoreactive bands of different mobility were detected (see Fig. 2), that could be associated to peptide multimerization. No accumulation of the BP178-immunoreactive band was observed in protein extracts obtained from embryos, leaves or roots from plants that expressed the BP178 gene under the control of the seed-specific promoter (Fig. 2d).

LC-MS/MS proteomic analyses allowed the detection of tryptic-derived peptides from BP178 that were unequivocally identified in the BP178-enriched protein body fraction of $p$ Glb1:BP178 lines, but not in the empty vector controls. The expected tryptic fragments for the peptide are indicated in Additional file 1 (highlighted sequences). LC-MS/MS data also confirmed that the $\sim 8 \mathrm{kDa}$ immunodetected polypeptide (Figs. 2c and 3; Additional file 4) corresponded to the expected BP178 peptide in seeds of the $p G l b 1: B P 178$ lines, whereas the tryptic peptides from the Glb1 signal peptide were not detected in the PB samples. Analysis by LC-MS/MS also demonstrated that BP178 accumulated in the protein body enriched fraction obtained from $p G l u B 1: B P 178$ and $p$ GluB4:BP178 seeds, but at very low levels $(\sim 3$ fmols $/ \mu \mathrm{L}$ ). Among the three strategies assessed for AMP production, the $p G l b 1: B P 178$ seeds showed the highest levels of BP178 accumulation. Among other factors, the orientation of the expression cassettes could be associated with the increased expression of the BP178 gene in the $p G l b 1: B P 178$ compared to that of $p G l u B 1: B P 178$ or pGluB4:BP178 seeds.

Further analysis confirmed that the BP178 peptide remained stable during the germination process, as the peptide was detected in the endosperm tissue of the germinating seeds (3 and 7-day germinated seeds). No BP178-related degradation products were observed in protein extracts from germinating seeds (Fig. 3). Moreover, the in planta produced BP178 peptide was found to accumulate in a stable manner during storage of the 

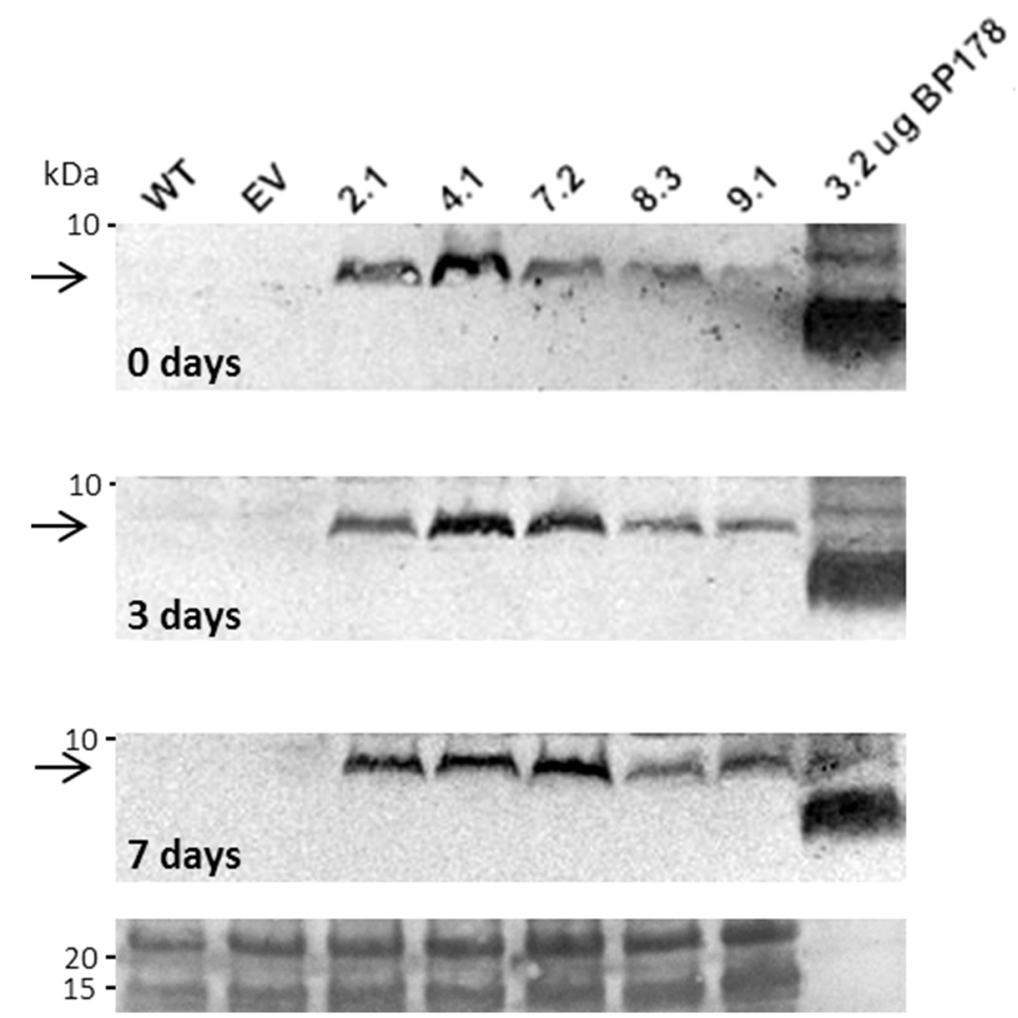

Fig. 3 Stability of the BP178 peptide accumulated in 3 years-old seeds. The endosperm tissue was manually dissected from mature seeds (0-days) and germinating rice seeds ( 3 and 7 days of germination). Protein extracts $(35 \mu \mathrm{g})$ were separated by Tricine-SDS gels, transferred onto PVDF membrane, and incubated with the anti-BP178 antibody followed by anti-rabbit lgG (Fc) alkaline phosphatase conjugated secondary antibody. EV, rice plants with the empty PCAMBIA 1300 vector were used as a negative control, and $3.2 \mu \mathrm{g}$ of synthetic BP178 were used as reference control. Arrows, indicate BP178 A-related bands in rice extracts. Numbers in the left side indicate the size of the molecular markers (kDa). Lower panels show Ponceau staining of protein samples

rice seeds as it could be detected in the transgenic seeds even after long periods of storage (up to 3 years), when stored at room temperature.

\section{Preparative scale purification and yield estimation of the BP178 peptide produced in seeds of transgenic rice} Knowing that the BP178 peptide accumulates in the rice endosperm being detected in the $\mathrm{PB}$ enriched fraction, we focused on the development of a method suitable for purification of this peptide from transgenic rice seeds at a preparative scale. The transgenic line 7 , harbouring the $p G l b 1: B P 178$ gene construct presented the highest level of resistance to Dickeya sp. infection (see below). For this, transgenic plants harbouring the $p$ Glb1:BP178 (line 7) were selected. $\mathrm{PB}$ enriched fractions were obtained from 1.500 seeds $(30 \mathrm{~g})$ of transgenic $p$ Glb1:BP178 event. As control, PB fractions were obtained from empty vector plants. The procedure used for purification of BP178 from rice seeds is shown in Fig. 4a. In each case, approximately $250 \mathrm{mg}$ of $\mathrm{PB}$ proteins were obtained. Next, protein extracts were obtained from $\mathrm{PB}$ enriched fraction by precipitation using acetone-TCADTT. Interestingly, under these conditions, the BP178 was found to be soluble, and the precipitated seed storage proteins were easily removed from the protein body extracts by centrifugation. BP178 peptide was recovered from the acetone fraction, processed as described in the experimental procedures, and further used. Western blot analysis confirmed the presence of BP178 peptide in the acetone fraction (Fig. $4 \mathrm{~b}$ ). This procedure was used to recover the BP178 peptide accumulating in seeds of five independent $p$ Glb1:BP178 lines. The BP178 lines accumulated the peptide in the range of 0.17 to $0.41 \mu \mathrm{g}$ /grain, as determined by western-blot analysis using dilution series of BP178 (Fig. 4c). The highest contents of BP178 was found in rice seeds of line 4.1, as $0.410 \pm$ $0.037 \mu \mathrm{g} /$ grain $(21 \mu \mathrm{g} / \mathrm{g}$ of seed, $6.33 \mathrm{pmols} / \mathrm{mg}$ of seed). The mean BP178 peptide yield for the 5 homozygous BP178 lines was $0.299 \pm 0.039 \mu \mathrm{g}$ BP178/grain for the 3 year-old seeds, and $0.252 \pm 0.085 \mu \mathrm{g}$ BP178/grain in the case of fresh seeds ( 0 year-old seeds). There were no statistically significant differences between the BP178 


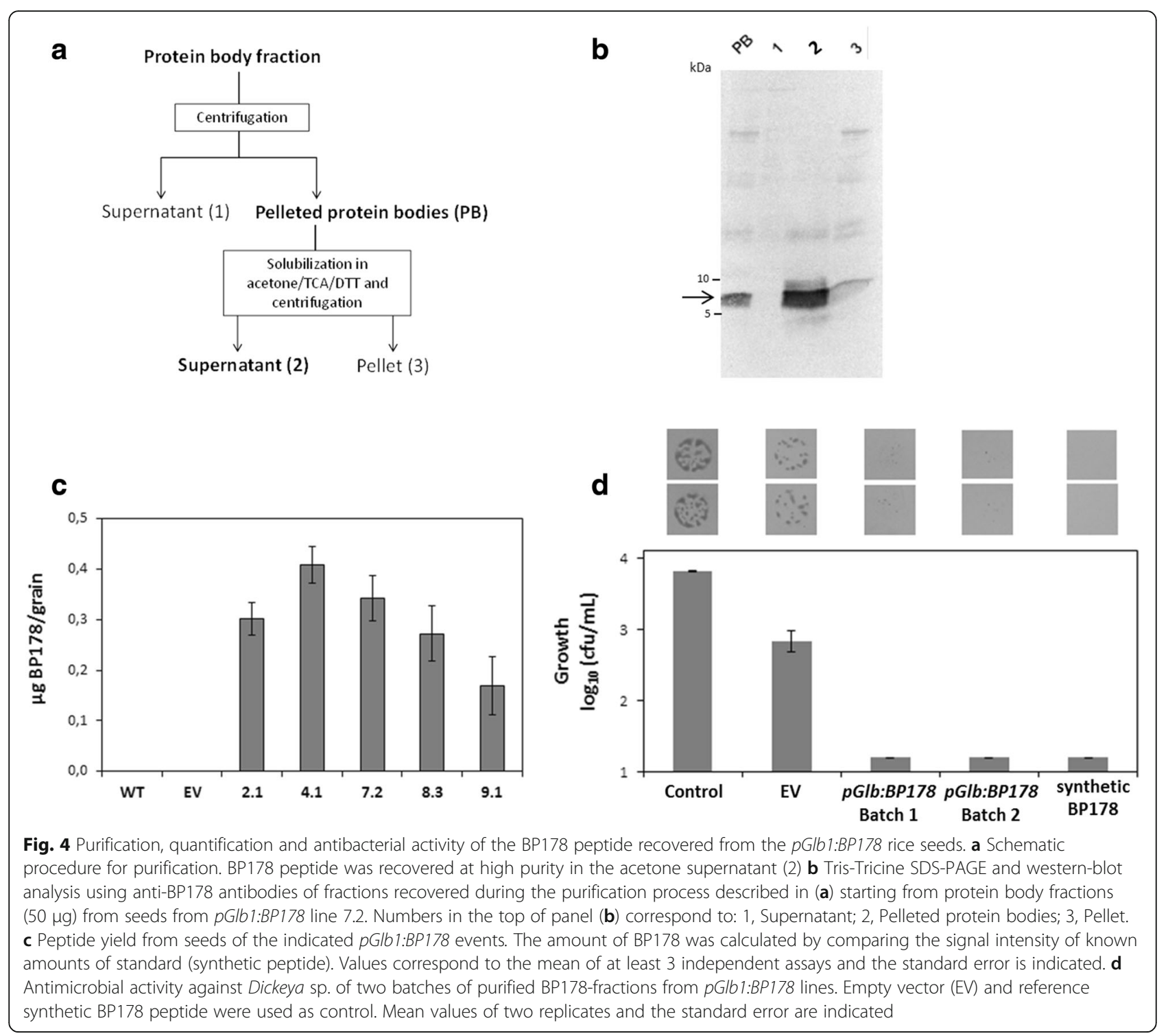

accumulation levels among 0 year-old and 3 year-old seeds, according to an ANOVA analysis $(F=0.251 ; P=0.630)$.

\section{BP178 peptide produced in rice seeds exhibits biological activity}

The antimicrobial activity of the in planta produced BP178 peptide was assessed against the seedling bacterial pathogen Dickeya sp. using a contact test. The bacterial suspension was incubated with BP178 purified from pGlb1:BP178 seeds or with purified fractions from empty vector seeds. The BP178 contents of the two batches of plant derived BP178 used were 0.41 and $0.46 \mu \mathrm{g} / \mu \mathrm{l}$, respectively. As expected, empty vector $\mathrm{PB}$ enriched fractions had no BP178. Therefore, in the antimicrobial activity assay, the corresponding total amounts were for the synthetic BP178 of $0.05 \mu \mathrm{g}$, and for the purified BP178 from transgenic seeds of 2.12 and $2.28 \mu \mathrm{g}$, for each batch, respectively. The plant derived BP178 extracts and the reference synthetic BP178 peptide gave similar bactericidal activities (Fig. 4d), but the concentrations of the plant derived BP178 peptide were around forty times higher.

\section{Enhanced resistance of BP178-rice seeds to infection by bacterial and fungal plant pathogens}

Because the BP178 was found to accumulate in the rice seeds, we investigated resistance to pathogen infection in germinating seeds and seedlings. Dickeya sp. 155210.1, a seedling bacterial pathogen, was used (Fig. 5). In the presence of Dickeya sp., seedlings expressing pGlb1:BP178 and pGluB4:BP178 were able to germinate and presented normal root and shoot morphology comparable to that of control seedlings. These seedlings, showed a consistent phenotype of resistance to infection 


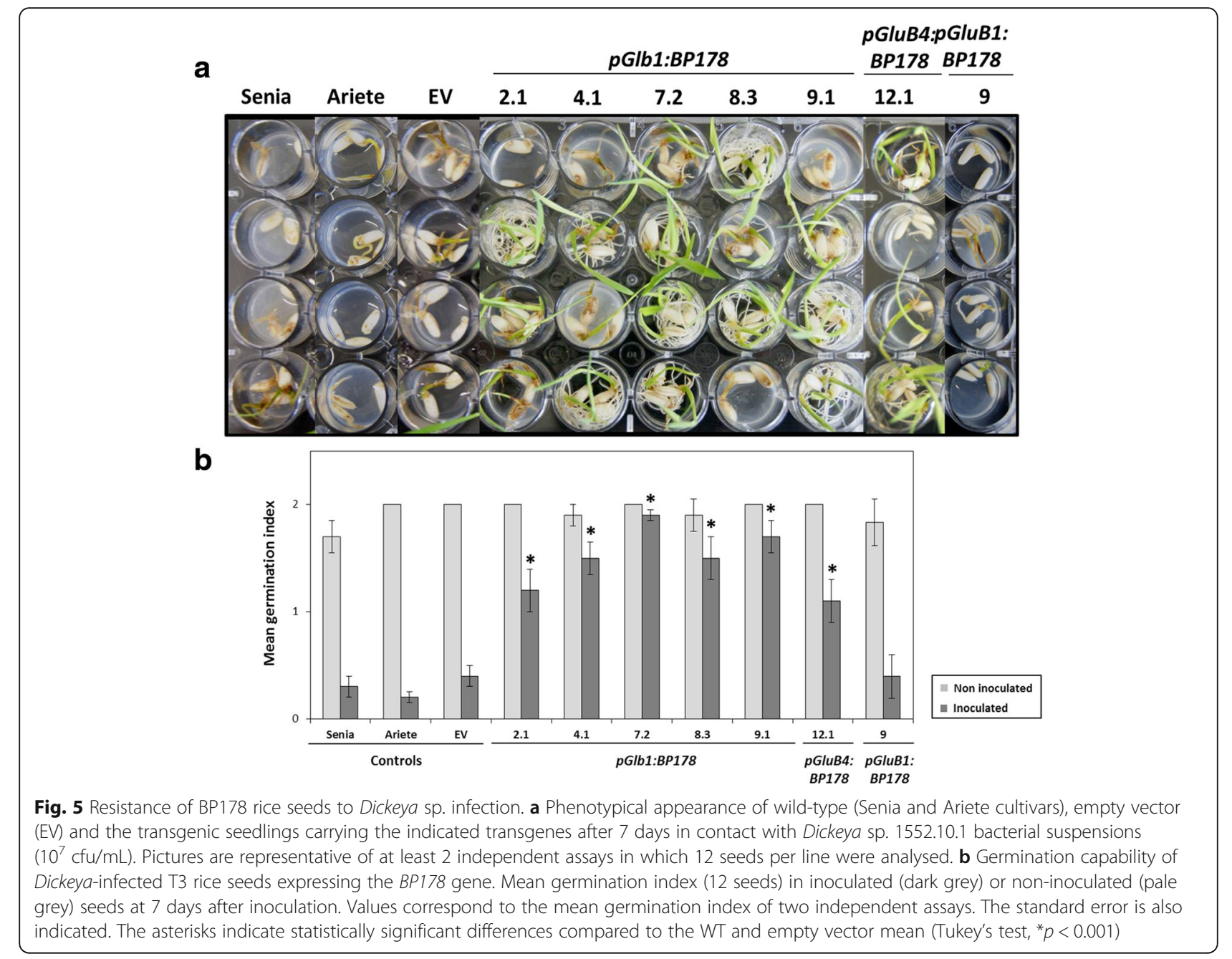

compared to control plants (WT, empty vector) that showed susceptibility to Dickeya infection. Differences in susceptibility occurred among lines harbouring the same transgene. In contrast, the $p G l u B 1: B P 178$ lines showed susceptibility to Dickeya sp., at similar levels than control seeds. These plants exhibited short and brownish shoots, and in most cases were unable to germinate in the presence of the bacterial phytopathogen.

Resistance of BP178-rice seedlings against $F$. verticillioides, a seed-borne fungal pathogen associated with Bakanae in rice, was also assessed. It was observed a better germination capability of the fungal-infected transgenic seeds expressing the $B P 178$ gene under the control of an endosperm-specific promoter, compared to control seeds (WT, empty vector) (Fig. 6). Most of WT and EV seeds were unable to germinate in the presence of the fungal pathogen and in some cases infected seedlings also show crown and stem rot, as well as low number of roots. More in detail, the expression of a BP178 gene under the control of the GluB1 and Glb1 promoter resulted in higher level of protection to $F$. verticillioides infection than GluB4:BP178-seeds.

\section{Discussion}

In this work, we generated transgenic rice plants accumulating the BP178 peptide in the rice seed endosperm, using endosperm-specific promoters to drive transgene expression. The DNA sequence encoding the $\mathrm{N}$-terminal signal peptide of rice storage proteins was fused to the BP178 gene, which also contained a C-terminal extension encoding the KDEL sequence for retention in the ER. The homozygous rice seeds accumulating the BP178 peptide showed resistance to infection by two plant pathogens, suggesting that the in planta-produced peptide was biologically active. Moreover, the BP178 peptide was easily purified from the transgenic rice seeds and was biologically active. There are several lines of evidence to suggest that BP178 accumulates in PBs, while subcellular location was not confirmed by direct methods (e.g. immunolocalization). Such evidences include the 


\section{a}
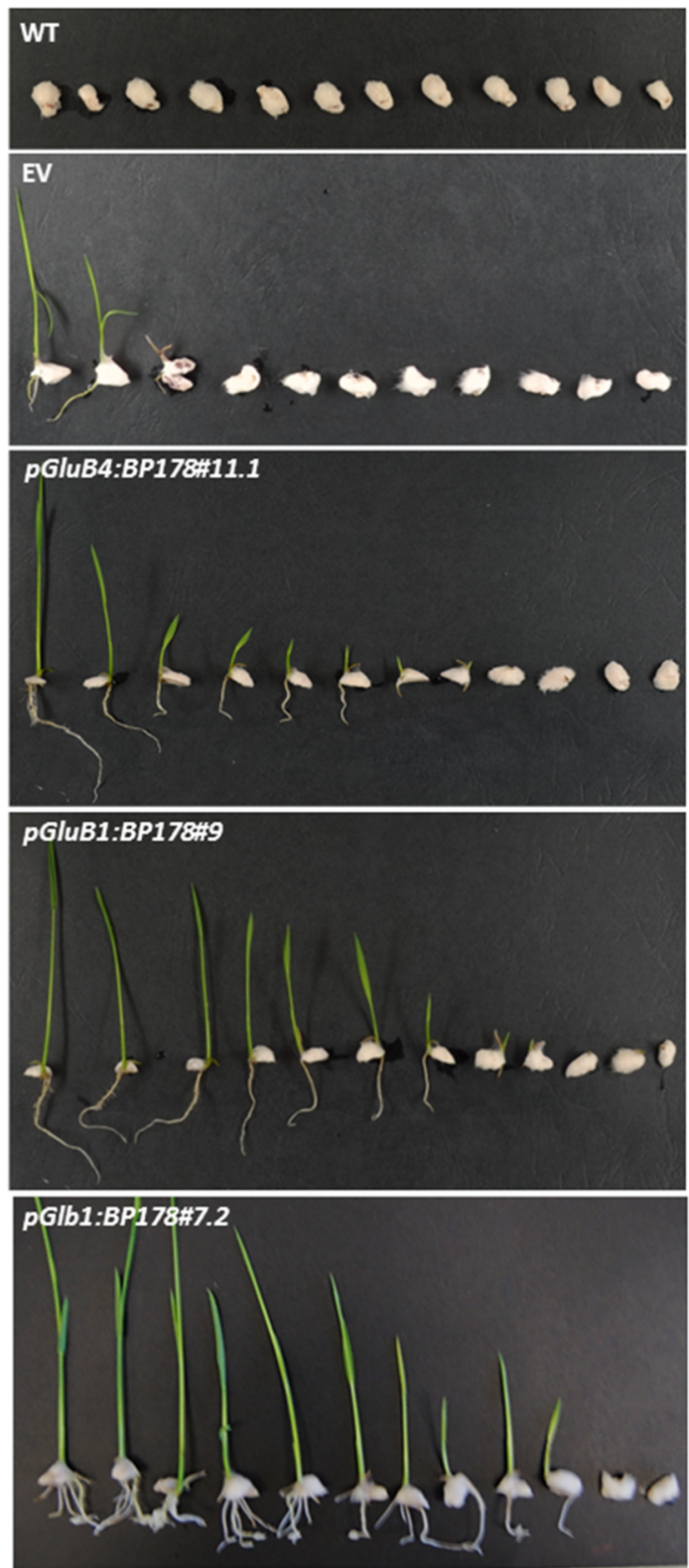

b

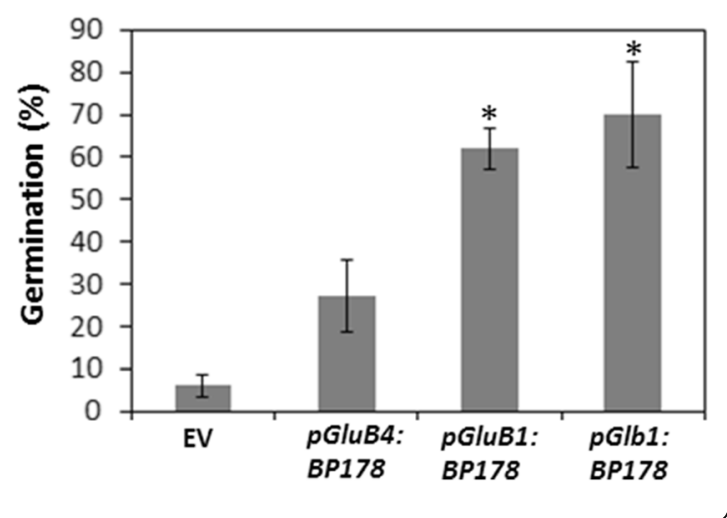

Fig. 6 Resistance of BP178-rice seeds to Fusarium verticillioides infection. a Phenotypical appearance of wild-type (WT) and transgenic seedlings carrying the indicated transgenes or the empty vector (EV) 7 days after germination in contact with F. verticillioides spore suspensions $\left(10^{5}\right.$ spores $\left./ \mathrm{mL}\right)$. Pictures are representative of 3 independent assays $\mathbf{b}$ Germination capability of the fungal inoculated transgenic seeds referred to wild-type seeds. Values correspond to the mean germination rate and standard errors of three independent assays in which at least 3 independent lines per transgene were analysed. Asterisks denote statistically significant differences with wild-type and empty vector plants (Tukey's test, ${ }^{*} p<0.001$ )

accumulation of a similar protein peptide ( $\mathrm{Cec} A$ ) to $\mathrm{PBs}$ when identical regulatory sequences were utilized for cloning and transformation, and also the presence of BP178 in cell fractions that have been shown to be enriched for protein bodies $[53,54]$.

It is worthwhile to mention that previous studies failed to obtain stable transgenic rice plants expressing certain BP100 derivative genes under the control of a constitutive promoter, suggesting toxicity of these AMPs to the host plant $[55,56]$. In a few cases, the $B P 100$ derivative genes were constitutively expressed in rice, but resulted in abnormal development of the plants [55]. On the other hand, the suitability of endosperm-specific promoters to drive expression of the cecropin $A$ gene in the rice endosperm has been demonstrated [54]. Altogether, these findings highlight the relevance of using the appropriate strategy for production of AMPs in transgenic rice to avoid undesirable effects, particularly for production of the BP178 antibacterial peptide in rice seed tissues.

The BP178 peptide accumulated in the endosperm tissue of the transgenic seeds, but not in embryo, leaf or root tissues, which is in agreement with the already described seed-specific activity of the GluB1, GluB4 and Glb1 promoters [35]. It is known that both glutelin and globulin rice seed storage proteins are synthesized in the endoplasmic reticulum and deposited in the PBII (also called protein storage vacuoles, [57]) of rice endosperm, due to cis-acting RNA localization signals present in the transcripts [58]. However, the sorting signals for seed storage proteins deposition into PBII have not yet been identified in rice [59]. Our results illustrate the utility of using an endosperm-specific promoter and signal peptide sequence of seed storage proteins for production of BP178 in protein body enriched fractions of transgenic rice seed. In this context, there are examples with other peptides in which a similar strategy has been successful [54] as well as unsuccessful [60]. Therefore, it should be considered the possibility that the BP178 peptide accumulates without the targeting signal sequence in the signal peptide. For instance, the BP178 peptide might interact with seed storage proteins, as has been previously described for other peptides [40,61]. Even, protein aggregation may also play a role in protein sorting, as it 
has been reported for human lysozyme that contains an internal targeting signal which directs the recombinant protein to the PBs [62]. Clearly, further studies are required to confirm targeting of the BP178 peptide to PBs and to identify the molecular determinants involved.

Fractionation procedures, in combination with western-blot and LC-MS/MS analyses allowed us to demonstrate that the BP178 peptide was efficiently produced and accumulated in the endosperm in BP178transgenic events. In addition, this production was without apparent interference on the accumulation of the seed storage proteins such as glutelins and prolamins. In contrast, other studies reported adverse effects of peptide accumulation in rice seeds. For instance, the production of transgenic rice seeds accumulating the major Japanese cedar pollen allergens, Cry $\mathrm{j} 1$ and Cry $\mathrm{j} 2$ at high levels, was accompanied by an important reduction in the accumulation of endogenous seed storage proteins [63]. Similarly, a high level of accumulation in the transgenic seeds of a hybrid peptide comprising seven predominant human $\mathrm{T}$ cell epitopes resulted in alterations in the accumulation of seed storage proteins [64]. Presumably, the accumulation of the BP178 peptide in the endosperm of the rice seed prevents the ER stress response as previously described by other authors [65]. Alternatively, the accumulation of the BP178 might not have reached the threshold level required to induce ER stress.

The in planta produced BP178 peptide exhibited an apparent molecular weight in Tris-Tricine SDS-PAGE (mobility) higher than expected ( $\sim 8 \mathrm{kDa}$ compared to $3.2 \mathrm{kDa}$ for this synthetic peptide). A similar phenomenon has been reported in transgenic plants expressing other AMPs $[54,55,60,66]$. Different possibilities can explain the abnormal electrophoretic mobility of the plant produced BP178 peptide, such as the formation of self-assembled peptide multimers, an additional amino acidic fragment between the $\mathrm{C}$-terminal of the signal peptide sequence (SGA-) and the N-terminal sequence of the BP178 peptide ( $-\mathrm{KKL})$, post-translational modifications or an improper processing of the signal peptide. However, the tryptic peptide corresponding to the signal peptide was not detected by LC-MS/MS analysis of the seed produced BP178 peptide. It is also known that proteins that enter into the secretory pathway are often modified in plant cells by the addition of sugar chains. Probably, the strong basic and amphipathic character of the BP178 and/or multimerization might be responsible of its abnormal electrophoretic mobility in SDS-PAGE gels.

A successful use of rice seeds as biofactories of AMPs requires the stable expression of the transgene through successive generations of plants, as well as stability of the peptide during seed storage. BP178 accumulation remained stable during storage of the rice seeds, at least for three years, without significant loss of antimicrobial activity. This stability can be associated to the adequate biochemical environment of the PBs, which might protect the peptide from the action of endogenous proteases $[27,29,31,54]$. Furthermore, the amino acid composition and structure of the BP178 peptide can be also responsible for the integrity of the peptide under these conditions as has been argued for other peptides [53].

In the present work, a simplified method to recover BP178 peptide from seeds was developed. The procedure consists of a two-step centrifugation to partially-purify protein bodies, from which the peptide was solubilized in an acetone mix, whereas the seed storage proteins were precipitated and removed. The plant derived BP178 peptide showed bactericidal activity. Although the activity was similar to the synthetic BP178 peptide, the concentrations were around forty times higher. It is possible there was a loss of activity of the plant derived BP178 peptide related to its abnormal electrophoretic mobility.

In the literature there are many examples of AMP genes that have been successfully expressed in rice to obtain disease resistant transgenic plants [56, 66-71]. However, less attention has been paid to develop plant biofactories for the production of AMPs and to recover the expected product. The processes for extraction and purification of peptides in general and of cationic amphipathic AMPs in particular, are often laborious and costly, often requiring several steps $[42,72]$, and frequently complicated by the interaction of the expression product with tissue components or with the equipment used $[40,54,73]$.

Current literature on production of peptides in rice seeds shows both successful and unsuccessful experiences, but in most cases repeated tandems or fusion proteins were used [52, 74-76]. The system here developed for production of BP178 was efficient without the need of using repeated tandems or fusion of the AMP to a larger protein carrier.

Among the three strategies assayed in this work (e.g. promoter used to drive transgen expression), seeds from $p$ Glb1:BP178 rice plants showed the highest accumulation levels of BP178 in the seed endosperm (up to $21 \mu \mathrm{g} / \mathrm{g}$ of seed, as revealed by western blot analysis and densitometric quantification). However, this value may represent an underestimation of the actual concentrations, because immunoblot detection of short and basic AMPs might underestimate the peptide yield $[55,66$, 77]. In addition, the yield of BP178 (6.33 pmols/mg of seed) was in the upper range of the above mentioned reports (0.03 to $10 \mathrm{pmols} / \mathrm{mg}$ of seed) and four times higher than for cecropin A using a similar strategy (1.5 pmols/mg of seed) [54]. The observation that the in planta produced BP178 peptide was biologically active and effectively protects germinating seeds against phytopathogens is in agreement with the accumulation of effective levels to confer antimicrobial activity [52]. This data 
additionally shows that the production of BP178 appears as a useful approach for engineering broad-spectrum protection against seed-borne pathogens in rice grains.

In summary, the strategy presented here for expression of peptide BP178 solves the limitation that was encountered with genes encoding highly cationic $\alpha$-helical small peptides showing toxicity towards the host plant $[55,56]$. Overall, these results suggest that the endosperm tissue of the rice seed can be considered as an appropriated platform for the accumulation of BP178, with no need of complex downstream processing steps for the elimination of endogenous storage proteins. The method requires minimum purification and processing steps, due to the solubility in acetone of the transgene product, with a yield suitable for their purification and further use of BP178 as an antimicrobial agent. The system also allows for longterm storage of the AMP-accumulating rice seeds and does not affect the normal growth and development of the plant. Thus, the rice-based BP178 peptide plant biofactory offers new possibilities for the sustainable production of this peptide and application, not only in crop protection, but also in other fields (pharmaceuticals, preservatives).

\section{Conclusions}

The strategy presented here for expression of peptide BP178 solve the limitation that was encountered with genes encoding highly cationic $\alpha$-helical small peptides showing toxicity towards the host plant. Overall, these results suggest that the endosperm tissue of the rice seed can be considered as an appropriated platform for the accumulation of BP178, with no need of complex downstream processing steps for the elimination of endogenous storage proteins. The method requires minimum purification and processing steps, due to the solubility in acetone of the transgene product, with a yield suitable for their purification and further use of BP178 as an antimicrobial agent. The system also allows for long-term storage of the AMP-accumulating rice seeds and does not affect the normal growth and development of the plant. Thus, the rice-based BP178 peptide plant biofactory offers new possibilities for the sustainable production of this peptide and application, not only in crop protection, but also in other fields (pharmaceuticals, preservatives).

\section{Methods}

\section{Construction of vectors for rice transformation}

Synthetic BP178 gene was designed based on the codon usage bias in Oryza sativa, chemically synthetized and cloned into the pUC57 plasmid (GenScript).

Three constructs for the expression of the BP178 gene in rice plants were prepared (Fig. 1).

To drive expression of the $B P 178$ gene, three rice seed endosperm-specific promoters were chosen: glutelin $B-1$ (GluB1), glutelin B-4 (GluB4) and 26 kDa $\alpha$-globulin (Glb1)
[35]. Additionally, the signal peptide sequence of the corresponding rice endosperm storage protein (GluB1, GluB4 or $26 \mathrm{kDa}$ Glb1) was fused to the N-terminus of the BP178 peptide sequence to direct its internalization into the ER system of the plant cell, and presented in Additional file 1: Figure S1. The sequence encoding the KDEL tetrapeptide (ER-retention signal) was added in C-terminal.

The various endosperm-specific promoters containing the $5^{\prime}$ untranslated region were isolated from genomic DNA obtained from rice leaves (Oryza sativa ssp. japonica cv. Senia, acquired from the rice source of the Centre for Research in Agricultural Genomics, Barcelona, Spain). Oligonucleotide primers designed according to the nucleotide sequences available at the EMBL/ GenBank/DDBJ nucleotide sequence database with accession numbers AY427569 (GluB1), AY427571 (GluB4) and AY427575 (Glb1) [35] for the Nipponbare japonica rice cultivar are shown in Additional file 5. The tissuespecificity and activity of the three rice seed promoters used in this work was previously described [35]. The $26 \mathrm{kDa}$ globulin promoter was found to be active in the inner starchy endosperm tissue, whilst the glutelin promoters exhibited the highest promoter activity in the outer portion of the endosperm.

The nucleotide sequence for the nopaline synthase terminator (nos) from Agrobacterium tumefaciens was also obtained by PCR using the plasmid $p C:: p U b i: C e c-$ AKDEL:nos as the template [66]. All the PCR products were gel-purified using a DNA purification column and cloned into the pGEM ${ }^{\oplus} \mathrm{T}$-Easy plasmid. Briefly, the pGEM::nos and pGEM:endosperm promoter-signal peptide $(S P)$ vectors were digested with the appropriate restriction enzymes. The Nos terminator sequence was cloned downstream of the promoter-SP, resulting in plasmids pGEM:endosperm promoter-SP:nos. Subsequently, the synthetic BP178 gene was cloned into the $p G E M:: e n-$ dosperm promoter-SP:nos plasmid DNA using the indicated restriction enzymes (Fig. 1). Previously, restriction sites were introduced by PCR using the primers described in Additional file 6. After verification by sequencing, the complete cassette (endosperm promoterSP:BP178:nos) was cloned into the pCAMBIA1300 plant expression vector, which already contains the hptII (hygromycin phosphotransferase) gene encoding hygromycin resistance in the T-DNA region.

The resulting binary vectors were transferred to Agrobacterium tumefaciens EHA105 (obtained from the Centre for Research in Agricultural Genomics, Barcelona, Spain) [78] for the stable rice transformation.

Production and characterization of transgenic rice plants expressing the BP178 gene in seed tissues

Transgenic rice plants were produced by Agrobacteriummediated transformation [79] using the commercial 
cultivars Senia and Ariete (obtained from the rice source of the Centre for Research in Agricultural Genomics, Barcelona, Spain). Transformation with the pCAMBIA1300 empty vector was done in parallel as a control.

Transgene integration into the rice genome, and integrity was examined by PCR analysis using genomic DNA obtained from young leaves (T0 plants) [80]. PCR primers were designed to amplify either the $B P 178$ gene or the complete cassette for expression of the $A M P$ gene (that is the promoter:BP178:nos DNA fragment). The transgene copy number was estimated in all T0 regenerated plants (and T3 plants) by quantitative PCR (qPCR) targeting to either the AMP or the hptII genes (primers, Additional file 7). The single copy gene, $\beta$-actin, was used for normalization as previously described [54, 56, 81].

To obtain homozygous lines and to analyse the hptII inheritance, 24 randomly chosen $\mathrm{T} 1$ seeds of the selected T0 transgenic lines were germinated in the presence of hygromycin. The offspring homozygous for hptII gene was identified in the T2 lines, and T3 lines were obtained by self-pollination of T2 plants. The primary transgenic and next seed progenies were soil-grown to maturity in the greenhouse at $28{ }^{\circ} \mathrm{C} / 20{ }^{\circ} \mathrm{C}$ (day/night) using a $12 \mathrm{~h} / 12 \mathrm{~h}$ (day/night) photoperiod.

\section{Purification and detection of the BP178 peptide from protein bodies of rice seeds}

A simplified method for preparation of partially purified protein bodies was previously reported [54] and used in the present work. Briefly, 1500 (30 g of seed) dehulled mature seeds were soaked in water for $2 \mathrm{~h}$ and were homogenized at $4{ }^{\circ} \mathrm{C}$ in $100 \mathrm{~mL}$ of grinding buffer $(0.6 \mathrm{M}$ Sucrose, $\left.10 \mathrm{mM} \mathrm{Na} \mathrm{HPO}_{4}, \mathrm{pH} 7.5\right)$ and $7 \mathrm{~mL}$ of enriched protein body fraction were obtained. Protein extracts $(50 \mu \mathrm{g})$ from $\mathrm{PB}$ enriched fractions were analysed on a Tris-Tricine SDS-PAGE gel, blotted onto $0.2 \mu \mathrm{m}$ PVDF membrane and probed with the antibody raised against the BP178 peptide (1:2000, GenScript). Binding was detected using an Anti-Rabbit IgG (Fc) Alkaline Phosphatase conjugate secondary antibody (1:7500, Promega). The Western Blue ${ }^{\circ}$ Stabilized substrate served for visualization of alkaline phosphatase activity (Promega). The signal of the BP178 peptide accumulated in the $\mathrm{PB}$ of transgenic lines was quantified using the Quantity Tools Image Lab ${ }^{\text {Th }}$ Software (Version 4.1) included in the ChemiDoc ${ }^{\text {Tn }}$ XRS + System (Bio-Rad, USA), by comparing the band intensity of the BP178 produced in seeds to that of reference amounts of synthetic BP178 peptide at known concentrations, run in the same gel. Since synthetic peptide shows generally $n$ mer bands in western-blot analysis, the amount of the standard peptide was calculated taking into account the sum of all individual immunodetected bands. BP178 peptide was synthesized by the LIPPSO Laboratory (Innovation Laboratory in Organic Chemistry Processes and Products, University of Girona, Spain).

Crude protein from protein body enriched fraction was obtained by adding ice cold-acetone (acetone-TCADTT) containing $15 \%(v / v)$ TCA and $20 \mathrm{mM}$ DTT to the pelleted protein bodies, incubation for $60 \mathrm{~min}$ at $-20{ }^{\circ} \mathrm{C}$ and centrifugation at $13,000 \times \mathrm{rpm}$ for $23 \mathrm{~min}$ at $4{ }^{\circ} \mathrm{C}$. After centrifugation, the supernatant was recovered and evaporated to finally obtain a solid fraction enriched with BP178 peptide free of starch, cell debris and most of native seed storage proteins. Both, the supernatant and pellet were analysed.

The identification of the BP178 peptide in PB enriched fractions from transgenic rice seeds was performed using an Agilent 1200 Nanoflow HPLC coupled to a 4000 QTRAP LC-MS/MS hybrid triple quadruple/linear ion trap mass spectrometer using a microSpray source $(\mathrm{AB} /$ MDS Sciex) as described previously [54].

For the BP178 peptide, four transitions were selected, according to their relative intensity and $\mathrm{m} / \mathrm{z}$ greater than the precursor $\mathrm{m} / \mathrm{z}$ (Additional file 8).

\section{Antibacterial activity of the in planta produced BP178}

The antibacterial activity of BP178 peptide produced in rice seeds was assessed in vitro against Dickeya sp. 1552 10.1 (provided by Maria López, Reference Laboratory in Plant Pathogenic Bacteria, Instituto Valenciano de Investigaciones Agrarias, Valencia, Spain) and compared to that of synthetic BP178. Two batches of $25 \mathrm{mg}$ of the enriched protein body fraction (Additional file 5), were used to obtain a partially purified plant derived BP178, according to the procedure indicated in Fig. $4 \mathrm{a}$, and then the acetone supernatant was evaporated. The dried supernatant from the acetone-TCA-DTT treated protein bodies was used. Because TCA inhibited bacterial growth, it was removed from the dried extract using three consecutive washing cycles with $10 \mathrm{mM}$ acetic acid and evaporation. Finally, the dried BP178 acetate was solubilized in diethyl ether, evaporated, and resuspended in $20 \mu \mathrm{L}$ water for the antibacterial assay. Western analysis was used to determine the BP178 contents were in each batch. Empty vector PB enriched extracts were treated similarly than BP178-seeds and included as control. Also synthetic BP178 $(3.2 \mu \mathrm{M})$ followed the same steps of the above mentioned protocol used to obtain BP178 from seeds. For the assay, $10 \mu \mathrm{L}$ of the bacterial cells suspension $\left(2 \times 10^{4} \mathrm{cfu} / \mathrm{mL}\right)$ were mixed with $10 \mu \mathrm{L}$ of the $3.2 \mu \mathrm{M}$ synthetic BP178 or of the purified BP178 from transgenic seeds, and incubated for $2 \mathrm{~h}$ at $28{ }^{\circ} \mathrm{C}$.

All samples were prepared in duplicate. After incubation, aliquots of $10 \mu \mathrm{L}$ were plated onto LB agar and 
grown for $24 \mathrm{~h}$ at $28{ }^{\circ} \mathrm{C}$, and viable cells determined. The experiment was repeated twice.

\section{Resistance of BP178 rice seedlings to pathogen infection} A seed germination test was used to determine the resistance of BP178-seedlings to two plant pathogens, the bacterial pathogen Dickeya sp. and the seed-borne fungal pathogen Fusarium verticillioides (supplied by the Plant Health Services, Generalitat de Catalunya, Barcelona, Spain). For the bacterial pathogen the assay was performed as previously described with minor modifications [56]. Twelve surface-sterilized seeds were placed in 24-well culture chambers and inoculated with $500 \mu \mathrm{L}$ of water or a bacterial suspension $\left(10^{7} \mathrm{cfu} / \mathrm{mL}\right)$ and vacuum infiltrated. For the fungal pathogen the procedure was as previously reported [54]. Seeds were inoculated with $50 \mu \mathrm{l}$ of a spore suspension at a concentration of $10^{3}$ (cv. Senia) or $10^{5}$ (cv. Ariete) spores $/ \mathrm{ml}$ (water as germination control) on MS medium without sucrose. In both cases seeds were allowed to germinate at $28{ }^{\circ} \mathrm{C}$ for seven days, using a $12 \mathrm{~h} / 12 \mathrm{~h}$ (day/night) photoperiod under a photon flux of 110-150 $\mu \mathrm{mol} . \mathrm{m}^{-2} \cdot \mathrm{s}^{-1}$. Then, disease intensity was estimated using a semi-quantitative scale $(0$, not germinated seed; 0.5 , germinated seed with the seedling length less than $25 \%$ of control; 1.0 , germinated seed with the seedling length from 25 to less than $50 \%$ of control; 1.5 , germinated seed with the seedling length from 50 to less than $75 \%$ of control; and 2.0 , germinated seed with the seedling of the same length as the control seeds). Transgenic seeds were compared to WT and empty vector seeds, and to non-pathogen inoculated seeds.

\section{Additional files}

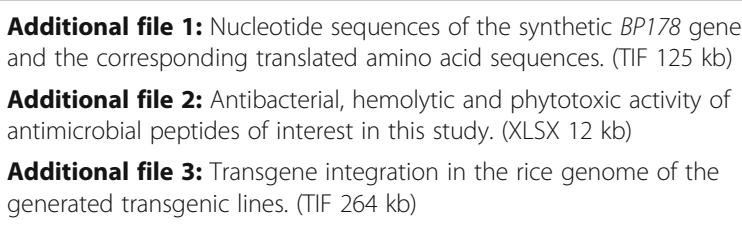

Additional file 4: Preparation of the PB fraction from rice seeds. (TFF $1091 \mathrm{~kb}$ ) Additional file 5: Accumulation of BP178 in seed protein body enriched fractions of $p$ Glb1:BP178 transgenic rice lines (T1 generation). (TIF $184 \mathrm{~kb}$ )

Additional file 6: Oligonucleotides used to amplify the rice seed promoter and its signal peptide coding region, the BP178 gene and the nopaline synthase terminator. (XLS $37 \mathrm{~kb}$ )

Additional file 7: Oligonucleotides used for quantitative polymerase chain reaction. (XLSX $11 \mathrm{~kb}$ )

Additional file 8: Selected transitions and parameters used in MS analysis of the BP178 peptide produced in rice seeds. (XLSX $10 \mathrm{~kb}$ )

\section{Abbreviations}

${ }^{\circ} \mathrm{C}$ : Degrees celsius; Aa: Amino acid; Ag: Antigen; AMP: Antimicrobial peptide; bp: Base pair; CaMV: Cauliflower mosaic virus; CE: Collision energy; Cec A: Cecropin A peptide; cfu/mL: Colony-forming units per millilitre; DP: Declustering potential; ER: Endoplasmic reticulum; EV: Empty vector;
F: Forward; Glb-1: 26 kDa a-globulin; GluB-1: Glutelin B-1; GluB-4: Glutelin B-4;

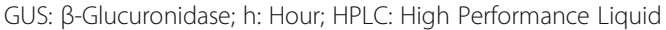

Chromatography; hpt II: Selection gene encoding resistance to hygromycin KDEL: ER retention signal sequence (aa sequence); LB: Left border; LB broth, agar: Luria-Bertani; LC-MS: Liquid Chromatography-Mass Spectrometry; m/ z: Mass divided by charge; mg: Milligram; MIC: Minimal inhibitory concentration; min: Minutes; mL: Millilitre; mM: Millimolar; Mw: Molecular weight; ng: Nanogram; nos: Nopaline synthase terminator; PB: Protein body; pGlb-1: Glb-1 promoter; pGluB-1: GluB-1 promoter; pGluB-4: GluB-4 promoter; pl: Isoelectric point; prom: Promoter; $p$ Ubi: Ubiquitin promoter; PVDF: Polyvinylidene difluoride; qPCR: Quantitative PCR; R: Reverse; RB: Right border; RS: Restriction site; SDS-PAGE: Sodium dodecyl sulphatepolyacrylamide gel electrophoresis; TCA: Trichloroacetic acid; term: Terminator; Tris: Tris (hydroxymethyl) aminomethane; WT: Wild-type; $\mu \mathrm{g}$ : Microgram; $\mu \mathrm{L}$ : Microlitre; $\mu \mathrm{M}$ : Micromolar; $\mu \mathrm{m}$ : Micrometre; umol: Micromol

\section{Acknowledgements}

We thank to Esther Izquierdo and Michel Rossignol from the Mass Spectrometry Proteomics Platform-MSPP, Laboratoire de Protéomique Fonctionnelle, INRA for support in the BP178 analysis; and to Eduard Bardaji from the LIPPSO Laboratory of the University of Girona for advice in purification of BP178 peptide. We are grateful to Sonia Campo for participating in the design of the constructs.

\section{Funding}

This work was supported by ERA-NET Plant-KBBE program EUI2008-03769 and EUI2008-03572 PROJECTS from the Spanish Ministry of Science and Innovation. We thank Government of the the Generalitat de Catalunya (Xarxa de Referencia en Biotecnología, and Xarxa de Referència en Tecnologia dels Aliments, SGR09626, 2008SGR812 and 2014SGR697) for support. We also thank the University of Girona for a Grant for Research improvement 2015-2018.

\section{Availability of data and materials}

The datasets supporting the conclusions of this article are included within the article (and its additional files). Nucleotide sequence data described in this article can be found in the GenBank database (http://www.ncbi.nlm.nih.gov/nucleotide) under the following accession numbers: AY427569 (GluB1), AY427571 (GluB4) and AY427575 (G/b1) for the Nipponbare japonica rice cultivar. Other material and data can be retrieved from the corresponding author upon request.

\section{Authors' contributions}

LM prepared the plant expression vectors, contributed to the rice transformation and carried out the molecular and phenotype analysis of transgenic lines, including the bacterial and fungal infection assays. Also carry out the preparative scale purification and the biological activity assays of the recovered peptide. MB carried out the rice transformation experiments and contributed to molecular and phenotype analysis of the transgenic lines, including the fungal infection assays. EB participated in the bacterial infection assays. EM, BSS and MC conceived, designed and coordinated the study. EM and LM wrote the manuscript. All the authors read and approved the final manuscript.

\section{Competing interests}

The authors declare that they have no competing interests.

Consent for publication

Not applicable.

Ethics approval and consent to participate Not applicable.

\section{Publisher's Note}

Springer Nature remains neutral with regard to jurisdictional claims in published maps and institutional affiliations.

\section{Author details}

${ }^{1}$ Institute of Food and Agricultural Technology-CIDSAV-XaRTA, University of Girona, Girona 17071, Spain. ${ }^{2}$ Centre for Research in Agricultural Genomics (CRAG), CSIC-IRTA-UAB-UB. Edifici CRAG, Campus de la UAB, 08193 Bellaterra, Barcelona, Spain. 
Received: 31 October 2016 Accepted: 6 March 2017

Published online: 14 March 2017

\section{References}

1. Andreu D, Rivas L. Animal antimicrobial peptides: an overview. Biopolymers. 1998;47:415-33.

2. Hancock RE. Cationic peptides: effectors in innate immunity and novel antimicrobials. Lancet Infect Dis. 2001;1:156-64.

3. Montesinos E. Antimicrobial peptides and plant disease control. FEMS Microbiol Lett. 2007;270:1-11.

4. Wang G, Li X, Wang Z. APD2: the updated antimicrobial peptide database and its application in peptide design. Nucleic Acids Res. 2009;37:933-7.

5. Zasloff M. Magainins, a class of antimicrobial peptides from Xenopus skin: isolation, characterization of two active forms, and partial cDNA sequence of a precursor. Proc Natl Acad Sci U S A. 1987:84:5449-53.

6. Montesinos E, Badosa E, Cabrefiga J, Planas M, Feliu L, Bardají E. Antimicrobial peptides for plant disease control. From discovery to application. In: Rajasekaran K, Cary J, Jaynes J, Montesinos E, editors. Small wonders: peptides for disease control. Washington: Oxford University Press; 2012. p. 235-61.

7. Badosa E, Ferre R, Planas M, Feliu L, Besalú E, Cabrefiga J, Bardají E, Montesinos E. A library of linear undecapeptides with bactericidal activity against phytopathogenic bacteria. Peptides. 2007;28:2276-85.

8. Ferré $\mathrm{R}$, Badosa E, Feliu L, Planas M, Montesinos E, Bardají E. Inhibition of plant-pathogenic bacteria by short synthetic cecropin A-melittin hybrid peptides. Appl Environ Microbiol. 2006;72:3302-8.

9. Marcos JF, Muñoz A, Pérez-Payá E, Misra S, López-García B. Identification and rational design of novel antimicrobial peptides for plant protection. Annu Rev Phytopathol. 2008;46:273-301.

10. Badosa E, Ferré R, Francés J, Bardají E, Feliu L, Planas M, Montesinos E. Sporicidal activity of synthetic antifungal undecapeptides and control of Penicillium rot of apples. Appl Environ Microbiol. 2009;75:5563-9.

11. Puig M, Moragrega C, Ruz L, Montesinos E, Llorente I. Postinfection activity of synthetic antimicrobial peptides against Stemphylium vesicarium in pear Phytopathology. 2014;104:1192-200.

12. Eggenberger $K$, Mink $C$, Wadhwani $P$, Ulrich AS, Nick P. Using the peptide BP100 as a cell-penetrating tool for the chemical engineering of actin filaments within living plant cells. ChemBioChem. 2011;12:132-7.

13. Soler M, González-Bártulos M, Soriano-Castell D, Ribas X, Costas M, Tebar F Massaguer A, Feliu L, Planas M. Identification of BP16 as a non-toxic cellpenetrating peptide with highly efficient drug delivery properties. Org Biomol Chem. 2014;12:1652-63.

14. Parachin NS, Mulder KC, Viana AA, Dias SC, Franco OL. Expression systems for heterologous production of antimicrobial peptides. Peptides. 2012;38:446-56.

15. Ingham $A B$, Moore RJ. Recombinant production of antimicrobial peptides in heterologous microbial systems. Biotechnol Appl Biochem. 2007:47:1-9.

16. Mattanovich D, Branduardi P, Dato L, Gasser B, Sauer M, Porro D. Recombinant protein production in yeasts. Methods Mol Biol. 2012:824:329-58.

17. Riggs AD. Bacterial production of human insulin. Diabetes Care. 1981;4:64-8.

18. Lico C, Desiderio A, Banchieri S, Benvenuto E. Plants as biofactories: Production of pharmaceutical recombinant proteins. In: Tuberosa R, Phillips $\mathrm{RL}$, Gale $\mathrm{M}$, editors. The wake of the double helix: from the green revolution to the gene revolution. Bologna: Avenue Media; 2005. p. 577-93.

19. De Gray G, Rajasekaran K, Smith F, Sanford J, Daniell H. Expression of an antimicrobial peptide via the chloroplast genome to control phytopathogenic bacteria and fungi. Plant Physiol. 2001;127:852-62.

20. Hefferon K. Plant-derived pharmaceuticals for the developing world. Biotechnol J. 2013:8:1193-202.

21. Horn ME, Woodard SL, Howard JA. Plant molecular farming: systems and products. Plant Cell Rep. 2004;22:711-20.

22. Hood EE, Christou P. Plant produced protein products. In: Howard JA, Hood EE, editors. Commercial plant-produced recombinant protein products case studies. Berlin Heidelberg: Springer; 2014. p. 1-11.

23. Kuo YC, Tan CC, Ku JT, Hsu WC, Su SC, Lu CA, Huang LF. Improving pharmaceutical protein production in Oryza sativa. Int J Mol Sci. 2013;14:8719-39.

24. Lee SG, Baichuan L, Shuangxia J, Daniell H. Expression and characterization of antimicrobial peptides Retrocyclin-101 and Protegrin-1 in chloroplasts to control viral and bacterial infections. Plant Biotechnol J. 2011;9:100-15.
25. Lico C, Santi L, Twyman RM, Pezzotti M, Avesani L. The use of plants for the production of therapeutic human peptides. Plant Cell Rep. 2012;31:439-51.

26. Ramessar K, Capell T, Christou P. Molecular farming in cereal crops. Phytochem Rev. 2008;7:579-92.

27. Stoger E, Ma JK, Fisher R, Christou P. Showing the seeds of success: pharmaceutical proteins from plants. Curr Opin Biotechnol. 2005;16:167-73.

28. Twyman RM, Stoger E, Schillberg S, Christou P, Fisher R. Molecular farming in plants: host systems and expression technology. Trends Biotechnol. 2003;21:570-8.

29. Delaney DE. Choice of crop species and development of transgenic product lines. In: Hood EE, Howard JA, editors. Plants as factories for protein production. Dordrecht: Kluwer Academics Publishers; 2002. p. 55-78.

30. Hood EE, Witcher DR, Maddock S, Meyer T, Baszczynski C, Bailey M, Flynn P, Register J, Marshall L, Bond D, Kulisek E, Kusnadi A, Evangelista R, Nikolov Z, Wooge C, Mehigh RJ, Hernan R, Kappel WK, Ritland D, Ping Li C, Howard JA. Commercial production of avidin from transgenic maize: characterization of transformant, production, processing, extraction and purification. Mol Breed. 1997;3:291-306.

31. Khan I, Twyman RM, Arcalis E, Stoger E. Using storage organelles for the accumulation and encapsulation of recombinant proteins. Biotechnol J. 2012;7:1099-108.

32. Witcher DR, Hood EE, Peterson D, Bailey M, Bond D, Kusnadi A, Evangelista R, Nikolov Z, Wooge C, Mehigh R, Kappel W, Register J, Howard JA. Commercial production of $\beta$-glucuronidase (GUS): a model system for the production of proteins in plants. Mol Breed. 1998;4:301-12.

33. Shin YJ, Hong SY, Kwon TH, Jang YS, Yang MS. High level of expression of recombinant human granulocyte-macrophage colony stimulating factor in transgenic rice cell suspension culture. Biotechnol Bioeng. 2003;82:778-83.

34. Su CF, Kuo IC, Chen PW, Huang CH, Seow SV, Chua KY, Yu SM. Characterization of an immunomodulatory Der p 2-FIP-fve fusion protein produced in transformed rice suspension cell culture. Transgenic Res. 2012;21:177-92.

35. Qu LQ, Takaiwa F. Evaluation of tissue specificity and expression strength of rice seed component gene promoters in transgenic rice. Plant Biotechnol J. 2004;2:113-25.

36. Wu CY, Suzuki A, Washida H, Takaiwa F. The GCN4 motif in a rice glutelin gene is essential for endosperm-specific expression and is activated by Opaque 2 in transgenic rice plants. Plant J. 1998;14:673-83.

37. Abe M, Yuki Y, Kurokawa S, Mejima M, Kuroda M, Park EJ, Scheller J, Nakanishi U, Kiyono H. A rice-based soluble form of a murine TNF-specific llama variable domain of heavy-chain antibody suppresses collageninduced arthritis in mice. J Biotechnol. 2014;175:45-52.

38. Lizuka M, Wakasa Y, Tsuboi H, Asashima H, Hirota T, Kondo Y, Matsumoto I, Takaiwa F, Sumida T. Suppression of collagen-induced arthritis by oral administration of transgenic rice seeds expressing altered peptide ligands of type II collagen. Plant Biotechnol J. 2014;12:1143-52.

39. Soh HS, Chung HY, Lee HH, Ajjappala H, Jang K, Park JH, Sim JS, Lee GY, Lee HJ, Han YH, Lim JW, Choi I, Chung IS, Hahn BS. Expression and functional validation of heat-labile enterotoxin B (LTB) and cholera toxin B (CTB) subunits in transgenic rice (Oryza sativa). Springerplus. 2015:4:148.

40. Takaiwa F, Yang L. Development of a rice-based peptide vaccine for Japanese cedar and cypress pollen allergies. Transgenic Res. 2014;23:573-84

41. Wang S, Takahashi H, Kajiura H, Kawakatsu T, Fujiyama K, Takaiwa F. Transgenic rice seeds accumulating recombinant hypoallergenic birch pollen allergen Bet $\vee 1$ generate giant protein bodies. Plant Cell Physiol. 2013:54:917-33.

42. Youngblood BA, Alfano R, Pettit SC, Zhang D, Dallmann HG, Huang N, MacDonald CC. Application of recombinant human leukemia inhibitory factor (LIF) produced in rice (Oryza sativa L.) for maintenance of mouse embryonic stem cells. J Biotechnol. 2014;172:67-72.

43. Takagi H, Saito S, Yang L, Nagasaka S, Nishizawa N, Takaiwa F. Oral immunotherapy against a pollen allergy using a seed-based peptide vaccine. Plant Biotechnol J. 2005:3:521-33.

44. Takagi H, Hiroi T, Hirose S, Yang L, Takaiwa F. Rice seed ER-derived protein body as an efficient delivery vehicle for oral tolerogenic peptides. Peptides. 2010;31:1421-5

45. Wakasa Y, Zhao H, Hirose S, Yamauchi D, Yamada Y, Yang L, Ohinata K, Yoshikawa M, Takaiwa F. Antihypertensive activity of transgenic rice seed containing an 18-repeat novokinin peptide localized in the nucleolus of endosperm cells. Plant Biotechnol J. 2011;9:729-35.

46. Cabanos C, Ekyo A, Amari Y, Kato N, Kuroda M, Nagaoka S, Takaiwa F, Utsumi S, Maruyama N. High-level production of lactostatin, a 
hypocholesterolemic peptide, in transgenic rice using soybean $\mathrm{A} 1 \mathrm{aB} 1 \mathrm{~b}$ as carrier. Transgenic Res. 2013;22:621-9.

47. Takagi H, Hiroi T, Yang L, Takamura K, Ishimitsu R, Kawauchi H, Takaiwa F. Efficient induction of oral tolerance by fusing cholera toxin B subunit with allergen-specific T-cell epitopes accumulated in rice seed. Vaccine. 2008:26:6027-30.

48. Wakasa Y, Tamakoshi C, Ohno T, Hirose S, Goto T, Nagaoka S, Takaiwa F. The hypocholesterolemic activity of transgenic rice seed accumulating lactostatin, a bioactive peptide derived from bovine milk $\beta$-lactoglobulin. $J$ Agric Food Chem. 2011;59:3845-50.

49. Yasuda H, Tada Y, Hayashi Y, Jomori T, Takaiwa F. Expression of the small peptide GLP-1 in transgenic plants. Transgenic Res. 2005;14:677-84.

50. Yoshida T, Kimura E, Koike S, Nojima J, Futai E, Sasagawa N, Watanabe Y, Ishiura S. Transgenic rice expressing amyloid $\beta$-peptide for oral immunization. Int J Biol Sci. 2011:3:301-7.

51. Matoba N, Doyama N, Yamada Y, Maruyama N, Utsumi S, Yoshikawa M. Design and production of genetically modified soybean protein with antihypertensive activity by incorporating potent analogue of ovokinin (2-7). FEBS Lett. 2001;497:50-4.

52. Badosa E, Moiset G, Montesinos L, Talleda M, Bardají E, Feliu L, Planas M, Montesinos E. Derivatives of the antimicrobial peptide BP100 for expression in plant systems. PLoS One. 2013;8:e85515.

53. Benchabane M, Goulet C, Rivard D, Faye L, Gomord V, Michaud D. Preventing unintended proteolysis in plant protein biofactories. Plant Biotechnol J. 2008;6:633-48.

54. Bundó M, Montesinos L, Izquierdo E, Campo S, Mieulet D, Guiderdoni E, Rossignol M, Badosa E, Montesinos E, San Segundo B, Coca M. Production of cecropin A antimicrobial peptide in rice seed endosperm. BMC Plant Biol. 2014;14:102.

55. Company N, Nadal A, La Paz JL, Martínez S, Rasche S, Schillberg S, Montesinos E, Pla M. The production of recombinant cationic a-helical antimicrobial peptides in plant cells induces the formation of protein bodies derived from the endoplasmic reticulum. Plant Biotechnol J. 2014;12:81-2.

56. Nadal A, Montero M, Company N, Badosa E, Messeguer J, Montesinos L, Montesinos E, Pla M. Constitutive expression of transgenes encoding derivatives of the synthetic antimicrobial peptide BP100: impact on rice host plant fitness. BMC Plant Biol. 2012;12:159.

57. Müntz K. Deposition of storage proteins. Plant Mol Biol. 1998;38:77-99.

58. Okita TW, Choi SB. mRNA localization in plants: targeting to the cell's cortical region and beyond. Curr Opin Plant Biol. 2002;5:553-9.

59. Takaiwa F, Wakasa Y, Takagi H, Hiroi T. Rice seed for delivery of vaccines to gut mucosal immune tissues. Plant Biotechnol J. 2015;13:1041-55.

60. Yasuda H, Hayashi Y, Jomori T, Takaiwa F. The correlation between expression and localization of a foreign gene product in rice endosperm. Plant Cell Physiol. 2006;47:756-63.

61. Takaiwa F, Hirose S, Takagi H, Yang L, Wakasa Y. Deposition of a recombinant peptide in ER-derived protein bodies by retention with cysteine-rich prolamins in transgenic rice seed. Planta. 2009;229:1147-58.

62. Yang D, Guo F, Liu B, Huang N, Watkins SC. Expression and localization of human lysozyme in the endosperm of transgenic rice. Planta. 2003;216:597-603.

63. Wakasa Y, Takagi H, Hirose S, Yang L, Saeki M, Nishimura T, Kaminuma O, Hiroi T, Takaiwa F. Oral immunotherapy with transgenic rice seed containing destructed Japanese cedar pollen allergens, Cry j 1 and Cry j 2, against Japanese cedar pollinosis. Plant Biotechnol J. 2013:11:66-76.

64. Takagi H, Hirose S, Yasuda H, Takaiwa F. Biochemical safety evaluation of transgenic rice seeds expressing $T$ cell epitopes of Japanese cedar pollen allergens. J Agric Food Chem. 2006;54:9901-5.

65. Vitale A, Ceriotti A. Protein quality control mechanisms and protein storage in the endoplasmic reticulum. A conflict of interests? Plant Physiol. 2004;136:3420-6.

66. Coca M, Peñas G, Gómez J, Campo S, Bortolotti C, Messeguer J, Segundo BS. Enhanced resistance to the rice blast fungus Magnaporthe grisea conferred by expression of a cecropin A gene in transgenic rice. Planta. 2006;223:392-406.

67. Imamura T, Yasuda M, Kusano H, Nakashita H, Ohno Y, Kamakura T, Taguchi S, Shimada $\mathrm{H}$. Acquired resistance to the rice blast in transgenic rice accumulating the antimicrobial peptide thanatin. Transgenic Res. 2010;19:415-24.

68. Jha S, Tank HG, Prasad BD, Chattoo BB. Expression of Dm-AMP1 in rice confers resistance to Magnaporthe oryzae and Rhizoctonia solani. Transgenic Res. 2009;18:59-69.
69. Jha S, Chattoo BB. Expression of a plant defensin in rice confers resistance to fungal phytopathogens. Transgenic Res. 2010;19:373-84.

70. Sharma A, Sharma R, Imamura M, Yamakawa M, Machii H. Transgenic expression of cecropin B, an antimicrobial peptide from Bombyx mori, confers enhanced resistance to bacterial leaf blight in rice. FEBS Lett. 2000;484:7-11.

71. Wang W, Wu C, Liu M, Hu G, Si H, Sun Z, Liu W, Fu Y. Resistance of antimicrobial peptide gene transgenic rice to bacterial blight. Rice Sci. 2011;18:10-6

72. Zhang D. Plant seed-derived human transferrin: expression, characterization and applications. OA Biotechnol. 2013;2:17.

73. Montesinos L, Bundó M, Izquierdo E, Campo S, Badosa E, Rossignol M, Montesinos E, San Segundo B, Coca M. Production of biologically active Cecropin A peptide in rice seed Oil bodies. PLoS One. 2016;11:e0146919.

74. Fujiwara Y, Aiki Y, Yang L, Takaiwa F, Kosaka A, Tsuji NM, Shiraki K, Sekikawa K. Extraction of human interleukin-10 from transgenic rice seeds. Protein Expr Purif. 2010;72:125-30.

75. Takagi H, Hiroi T, Yang L, Tada Y, Yuki Y, Takamura K, Ishimitsu R, Kawauchi $\mathrm{H}$, Kiyono H, Takaiwa F. A rice-based edible vaccine expressing multiple T cell epitopes induces oral tolerance for inhibition of Th2-mediated IgE responses. Proc Natl Acad Sci U S A. 2005;102:17525-30.

76. Torres E, Gonzalez-Melendi P, Stöger E, Shaw P, Twyman RM, Nicholson L, Vaquero C, Fischer R, Christou P, Perrin Y. Native and artificial reticuloplasmins co-accumulate in distinct domains of the endoplasmic reticulum and in post-endoplasmic reticulum compartments. Plant Physiol. 2001;127:1212-23.

77. Osusky M, Osuska L, Hancock RE, Kay WW, Misra S. Transgenic potatoes expressing a novel cationic peptide are resistant to late blight and pink rot. Transgenic Res. 2004;13:181-90

78. Hood EE, Gelvin SB, Melchers S, Hoekema A. New Agrobacterium helper plasmids for gene transfer to plants (EHA105). Transgenic Res. 1993;2:208-18.

79. Sallaud C, Meynard D, van Boxtel J, Gay C, Bès M, Brizard JP, Larmande P, Ortega D, Raynal M, Portefaix M, Ouwerkerk PB, Rueb S, Delseny M, Guiderdoni E. Highly efficient production and characterization of T-DNA plants for rice (Oryza sativa L.) functional genomics. Theor Appl Genet. 2003;106:1396-408.

80. Murray MG, Thompson WF. Rapid isolation of high molecular weight plant DNA. Nucleic Acids Res. 1980;8:4321-5.

81. Yang J, Barr LA, Fahnestock SR, Liu ZB. High yield recombinant silk-like protein production in transgenic plants through protein targeting Transgenic Res. 2005;14:313-24.

\section{Submit your next manuscript to BioMed Central and we will help you at every step:}

- We accept pre-submission inquiries

- Our selector tool helps you to find the most relevant journal

- We provide round the clock customer support

- Convenient online submission

- Thorough peer review

- Inclusion in PubMed and all major indexing services

- Maximum visibility for your research

Submit your manuscript at www.biomedcentral.com/submit
Biomed Central 